\title{
Leptin signaling axis specifically associates with clinical prognosis and is multifunctional in regulating cancer progression
}

\author{
Tsung-Chieh Lin ${ }^{1}$, Kuan-Wei Huang ${ }^{1}$, Chia-Wei Liu ${ }^{1}$, Yu-Chan Chang ${ }^{2}$, Wei-Ming \\ Lin $^{3}$, Tse-Yen Yang ${ }^{4}$ and Michael Hsiao ${ }^{2,5}$ \\ ${ }^{1}$ Genomic Medicine Core Laboratory, Chang Gung Memorial Hospital, Linkou, Taiwan \\ ${ }^{2}$ Genomics Research Center, Academia Sinica, Taipei, Taiwan \\ ${ }^{3}$ Department of Diagnostic Radiology, Chang Gung Memorial Hospital, Chiayi Branch, Chang Gung University of Science and \\ Technology, Chiayi, Taiwan \\ ${ }^{4}$ Department of Medical Research, China Medical University Hospital, China Medical University, Taichung, Taiwan \\ ${ }^{5}$ Department of Biochemistry, College of Medicine, Kaohsiung Medical University, Kaohsiung, Taiwan
}

Correspondence to: Michael Hsiao, email: mhsiao@gate.sinica.edu.tw

Keywords: leptin; leptin receptor; expression; survival; prognosis

Received: November 19,2017 Accepted: February 26, $2018 \quad$ Published: March 30, 2018

Copyright: Lin et al. This is an open-access article distributed under the terms of the Creative Commons Attribution License 3.0 (CC BY 3.0), which permits unrestricted use, distribution, and reproduction in any medium, provided the original author and source are credited.

\section{ABSTRACT}

Leptin is a peptide hormone that has been characterized as the ligand of leptin receptor (LEPR). The observation of leptin secretion and leptin receptor expression beyond the normal tissues suggests the potentially critical roles other than its physiological function. In addition to the original function in controlling appetite and energy expenditure, leptin-mediated signaling axis through leptin receptor is multifunctional which plays role in the regulation toward broad types of cancer. Emerging evidences has indicated leptin's function in promoting several processes which are relevant to cancer progression including cell proliferation, metastasis, angiogenesis and drug resistance. We relatively display leptin and leptin receptor expression levels in pan-cancer panel based on the transcriptome analysis via dataset The Cancer Genome Atlas (TCGA), and show the clinical association of the axis in predicting cancer prognosis. The results indicate the pathological impacts of this axis on many types of cancer. This review mainly focuses on leptin-mediated effects and its downstream signaling related to the progression of cancers, and displays the clinical significance of this axis including the impact on cancer patient survival.

\section{INTRODUCTION}

Leptin is the product of $O b(L E P)$ gene cloned in1994 by Friedman and colleagues, and was called leptin after the Greek "leptos" meaning thin [1]. Leptin was identified as a peptide hormone released by adipocytes which primarily functions as the ligand of leptin receptor $(L E P R)$ to regulate appetite and energy expenditure [2, $3]$. The recent discovery of leptin and leptin receptor expression level beyond the traditional tissues indicates that the signaling axis has a critical role outside of its physiological function. The tissues with leptin expression include placenta, stomach, fibroblast, mammary epithelium, and skeletal muscle [4-7]. Furthermore, emerging studies pointed out its expression in broad range of cancer types and also the leptin-dependent signaling in regulating several important factors in cancer progression including tumor proliferation, metastasis, angiogenesis and drug resistance. In this review, we focus on the pathological function of leptin-leptin receptor in cancer, and further illustrate the clinical significance based on the correlation with cancer patient outcomes. 


\section{Leptin and leptin receptor expression in cancer}

Cancer cells release leptin and express leptin receptor $(L E P R)$, which suggests the potential leptin autocrine/paracrine signaling loop could affect tumor progression. In colorectal carcinoma, relative leptin receptor level displayed the correlation with cancer cell proliferation and neoangiogenesis [8]. The California Santa Cruz (UCSC) Cancer Genomics Browser is a comprehensive analysis tool for understanding the cancer transcriptome data with matched clinical information [9]. The omics data were mainly generated by microarray and RNA sequencing analysis in combination with cancer patient's follow-up data in The Cancer Genome Atlas (TCGA). The results showed the relative leptin and leptin receptor expression in pan-cancer panel (Figure 1). The relative leptin expression level is highly found in bladder cancer, breast cancer, large B cell lymphoma, lung cancer, ovarian cancer, pancreatic cancer, testicular cancer. In addition, leptin receptor is relatively high expressed in kidney cancer, liver cancer, lung cancer, mesothelioma, ovarian cancer, pancreatic cancer, prostate cancer, sarcoma, thyroid cancer and acute myeloid leukemia, indicating the potential pathological role of this axis in cancers.

\section{The correlation with clinical outcome}

The clinical association of leptin or leptin receptor with cancer patient outcome had been explored. The expression of leptin and its receptor were found to be associated with endometrial cancer patient's poorer prognosis (3-year survival rate) [10]. A study in ovarian cancer cohort significantly showed the correlation of leptin and leptin receptor co-expression with shorter patient survival [11]. Furthermore, the increased serum leptin and leptin receptor mRNA expression revealed the positive correlation with cancer recurrence and mortality in triple-negative breast cancer [12]. In addition to the impact of the axis, leptin level alone displayed the positive correlation with poor outcome in ovarian cancer [13], and higher leptin level was found in multiple myeloma patients and associated with clinical stage [14]. Leptin receptor also displayed prognostic power in clinical. Patients of glioblastoma revealed poor prognosis as high leptin receptor levels were detected [15]. The association of leptin receptor with poor recurrence-free survival $(P=0.09)$ and cancer-specific survival $(P=0.01)$ by log-rank test was observed, and data from Cox regression analysis further characterized leptin receptor as an independent predictor of poor survival respectively with $P=0.011$ and 0.006 in upper tract urothelial carcinomas [16]. However, the observation of negative correlation with cancer progression has also been reported. Cytoplasmic immunohistochemical staining of leptin was less detected in breast cancer with poor survival [17]. In non-metastatic renal cell carcinoma, patients of high disease recurrence rate and poor recurrence-free survival correlated with high CpG methylation in leptin receptor gene [18]. Furthermore, the correlation of leptin and leptin receptor with cancer patient's survival outcome is listed (Table 1 $\& 2$ ). The expression profile was analyzed by microarray analysis or RNA sequencing technology using samples of cancer patients $[9,19,20]$. The results indicate the potential prognostic power of this axis in predicting the progression of specific cancer type.

\section{Leptin and cancer cell proliferation}

Leptin had been pointed out to regulate cell proliferation particularly in various type of cancer cells. The function in inducing ovarian cancer cell growth was mediated by the increased cyclin D1 and Mcl-1 expression via the activation of the MEK/ERK1/2 and PI3K/Akt signaling pathways [21]. Leptin was reported to promote the increase of esophageal adenocarcinoma OE19 cell proliferation, and the effect was observed to be inhibited by adiponectin receptor axis-mediated suppression of ubiquitin-like with PHD and ring finger domains 1 (UHRF1) [22]. Moreover, leptin alone and cotreatment with secreted phospholipase A2-IIA (sPLA2IIA) elicited phosphorylation activation of Src/ERK/ Akt/mTOR/p70S6K/rS6 pathway leading to increase of 1321N1 human astrocytoma cell proliferation [23]. In breast cancer, low dosage addition of leptin $(0.625$ $\mathrm{nM}$ ) significantly induced breast cancer cell growth via increased cell cycle transition. The expression of cell cycle and apoptosis associated factor including p53 and $\mathrm{p} 21 \mathrm{WAF} 1 / \mathrm{CIP} 1$ were further proved to be altered [24]. Another study further pointed out the positive correlation between leptin expression and proliferation pathway including leptin receptor, aromatase, mitogen activated protein kinase (MAPK) and signal transducer and activator of transcription-3 (STAT3) in breast cancer patients with estrogen receptor expression and obesity, suggesting the effect of leptin-leptin receptor axis in tumor microenvironment [25]. Similar findings from co-culture system had been reported that the leptin produced by obese adipose stromal/stem cells could enhance proliferation in estrogen receptor positive breast cancers [26]. In addition, the mediator of leptin-leptin receptor in triggering tumor proliferation was identified. APPL1 could directly bind to both STAT3 and leptin receptor to elevate leptin-induced phosphorylation of Akt, ERK1/2 and STAT3 in breast cancer MCF-7 and human hepatocellular carcinoma HepG2 [27], while a reverse function in rat hepatocellular carcinoma proliferation was also reported, this is, via a p38-MAPK-dependent signalling pathway in vitro to reduce serum-stimulated H4IIE HCC cell proliferation [28]. In human gallbladder cancer, the experiment result also demonstrated the function of leptin in promoting cell proliferation through leptin receptor $(O B-R b)$, revealing 
the requirement of leptin receptor in leptin-dependent cancer progression [29]. Clinically, the involvement of leptin receptors expression in proliferation of colorectal carcinoma patients had been observed. Absence in expression level of leptin receptor correlated with low tumor proliferation rate in $94.1 \%$ of the cases, while high proliferation rate associated with $92 \%$ of the cases with pronounced expression [8].
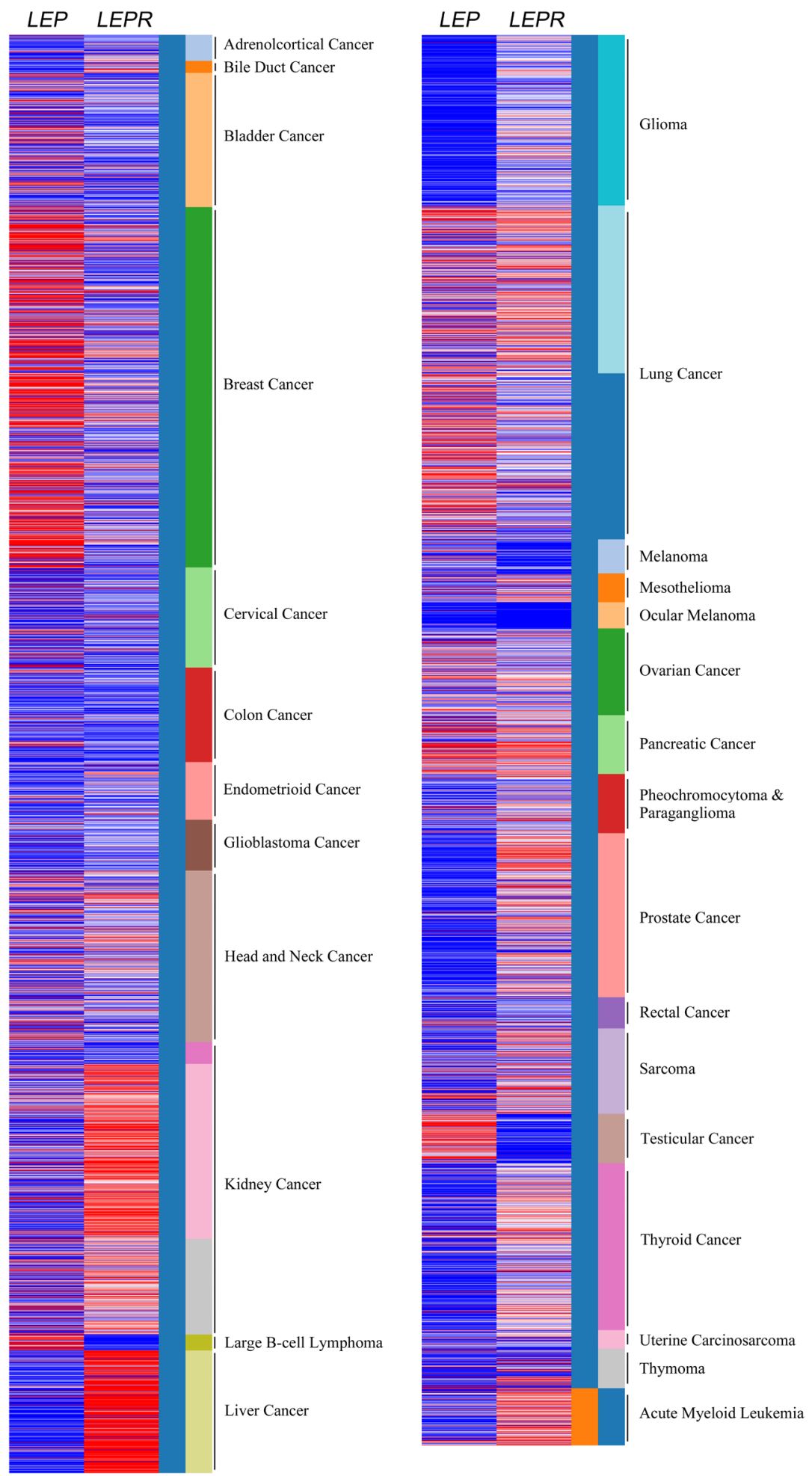

Figure 1: Relative leptin and leptin receptor expression in pan-cancer panel. In TCGA pan-cancer dataset, the relative leptin $(L E P)$ and leptin receptor $(L E P R)$ expression levels were showed in all cancer types. Red color in heat map represents genes with high expression. Blue color in heat map represents gene with low expression. 
Table 1: The correlation of leptin with cancer patient survival

\begin{tabular}{|c|c|c|c|c|c|c|c|c|}
\hline Symbol & Cance type & Prognosis & Endpoint & $p$ value & Case & Dataset/Cohort & Method & $\begin{array}{l}\text { Probe } \\
\text { ID }\end{array}$ \\
\hline LEP & Bladder urothelial carcinoma & - & Overall survival & N.S. & 390 & TCGA & RNA Seq & \\
\hline$L E P$ & Glioblastoma multiforme & - & Overall survival & N.S. & 538 & TCGA & RNA Seq & \\
\hline$L E P$ & Breast invasive carcinoma & Poor & Overall survival & 0.0013 & 962 & TCGA & RNA Seq & \\
\hline$L E P$ & $\begin{array}{c}\text { Cervical squamous cell } \\
\text { carcinoma }\end{array}$ & - & Overall survival & N.S. & 191 & TCGA & RNA Seq & \\
\hline$L E P$ & $\begin{array}{l}\text { Colon and rectum } \\
\text { adenocarcinoma }\end{array}$ & Poor & Overall survival & 0.025 & 467 & TCGA & RNA Seq & \\
\hline$L E P$ & Esophageal carcinoma & - & Overall survival & N.S. & 184 & TCGA & RNA Seq & \\
\hline$L E P$ & $\begin{array}{l}\text { Head and neck squamous cell } \\
\text { carcinoma }\end{array}$ & - & Overall survival & N.S. & 502 & TCGA & RNA Seq & \\
\hline$L E P$ & Acute myeloid leukemia & Poor & Overall survival & $1 \mathrm{E}-05$ & 168 & TCGA & RNA Seq & \\
\hline$L E P$ & Kidney pan cancer & - & Overall survival & N.S. & 792 & TCGA & RNA Seq & \\
\hline$L E P$ & $\begin{array}{l}\text { Liver hepatocellular } \\
\text { carcinoma }\end{array}$ & Poor & Overall survival & $3 \mathrm{E}-05$ & 361 & TCGA & RNA Seq & \\
\hline$L E P$ & Lung adenocarcinoma & - & Overall survival & N.S. & 475 & TCGA & RNA Seq & \\
\hline$L E P$ & $\begin{array}{c}\text { Ovarian serous } \\
\text { cystadenocarcinoma }\end{array}$ & - & Overall survival & N.S. & 578 & TCGA & RNA Seq & \\
\hline$L E P$ & Pancreatic adenocarcinoma & - & Overall survival & N.S. & 176 & TCGA & RNA Seq & \\
\hline$L E P$ & Prostate adenocarcinoma & - & Overall survival & N.S. & 497 & TCGA & RNA Seq & \\
\hline$L E P$ & Skin cutaneous melanoma & - & Overall survival & N.S. & 336 & TCGA & RNA Seq & \\
\hline$L E P$ & Stomach adenocarcinoma & - & Overall survival & N.S. & 352 & TCGA & RNA Seq & \\
\hline$L E P$ & Testicular germ cell tumors & - & Overall survival & N.S. & 133 & TCGA & RNA Seq & \\
\hline$L E P$ & Thymoma & - & Overall survival & N.S. & 118 & TCGA & RNA Seq & \\
\hline$L E P$ & Thyroid carcinoma & - & Overall survival & N.S. & 489 & TCGA & RNA Seq & \\
\hline$L E P$ & $\begin{array}{l}\text { Uterine corpus endometrioid } \\
\text { carcinoma }\end{array}$ & - & Overall survival & N.S. & 332 & TCGA & RNA Seq & \\
\hline$L E P$ & Breast cancer & Good & Overall survival & 0.037 & 1402 & $\begin{array}{c}\text { E-MTAB-365, E-TABM-43, } \\
\text { GSE: } 11121,12093,12276, \\
\text { 1456, 16391, 16446, 16716, } \\
\text { 17705, 17907, 18728, 19615, } \\
20194,20271,2034,20685, \\
20711,21653,2603,26971, \\
2990,31448,31519,32646, \\
3494,37946,41998,42568, \\
45255,4611,5327,6532, \\
7390,9195\end{array}$ & Array & $\begin{array}{c}207092 \\
\text { at }\end{array}$ \\
\hline$L E P$ & Gastric cancer & Poor & Overall survival & 0.0002 & 876 & $\begin{array}{c}\text { GSE: } 14210,15459,22377 \\
29272,51105,62254\end{array}$ & Array & $\begin{array}{c}207092 \\
\text { at }\end{array}$ \\
\hline$L E P$ & Soft tissue cancer & Good & $\begin{array}{l}\text { Distant } \\
\text { recurrence free } \\
\text { survival }\end{array}$ & 0.0006 & 140 & GSE30929 & Array & $\begin{array}{c}207092 \\
\text { at }\end{array}$ \\
\hline$L E P$ & Ovarian cancer & Poor & Overall survival & 0.0051 & 278 & GSE9891 & Array & $\begin{array}{c}207092 \\
\text { at }\end{array}$ \\
\hline$L E P$ & Colon rectal cancer & Poor & $\begin{array}{l}\text { Disease specific } \\
\text { survival }\end{array}$ & 0.0165 & 55 & GSE17537 & Array & $\begin{array}{c}207092_{-} \\
\text {at }\end{array}$ \\
\hline$L E P$ & Brain cancer (Glioma) & Poor & Overall survival & 0.046 & 74 & GSE4412-GPL96 & Array & $\begin{array}{c}207092 \\
\text { at }\end{array}$ \\
\hline LEP & Breast cancer & Poor & $\begin{array}{l}\text { Distant metastasis } \\
\text { free survival }\end{array}$ & 0.0489 & 200 & GSE11121 & Array & $\begin{array}{c}207092 \\
\text { at }\end{array}$ \\
\hline
\end{tabular}

Survival data was collected from database SurvExpress, TCGA and Kaplan Meier-plotter.

LEP: leptin. N.S.: no significance. 
Table 2: The correlation of leptin receptor with cancer patient survival

\begin{tabular}{|c|c|c|c|c|c|c|c|c|}
\hline Symbol & Cance type & Prognosis & Endpoint & $p$ value & Case & Dataset/Cohort & Method & Probe ID \\
\hline$L E P R$ & Adrenocortical carcinoma & Good & Overall survival & 0.0164 & 77 & TCGA & RNA Seq & \\
\hline$L E P R$ & Cholangiocarcinoma & - & Overall survival & N.S. & 35 & TCGA & RNA Seq & \\
\hline$L E P R$ & Bladder urothelial carcinoma & - & Overall survival & N.S. & 390 & TCGA & RNA Seq & \\
\hline$L E P R$ & Glioblastoma multiforme & - & Overall survival & N.S. & 538 & TCGA & RNA Seq & \\
\hline$L E P R$ & Breast invasive carcinoma & - & Overall survival & N.S. & 962 & TCGA & RNA Seq & \\
\hline$L E P R$ & Cervical squamous cell carcinoma & Poor & Overall survival & 0.0371 & 191 & TCGA & RNA Seq & \\
\hline$L E P R$ & Colon and rectum adenocarcinoma & Poor & Overall survival & 0.0309 & 467 & TCGA & RNA Seq & \\
\hline$L E P R$ & Esophageal carcinoma & - & Overall survival & N.S. & 184 & TCGA & RNA Seq & \\
\hline$L E P R$ & Uveal melanoma & Poor & Overall survival & 0.0495 & 80 & TCGA & RNA Seq & \\
\hline$L E P R$ & $\begin{array}{l}\text { Head and neck squamous cell } \\
\text { carcinoma }\end{array}$ & - & Overall survival & N.S. & 502 & TCGA & RNA Seq & \\
\hline$L E P R$ & Acute myeloid leukemia & - & Overall survival & N.S. & 168 & TCGA & RNA Seq & \\
\hline$L E P R$ & Kidney pan cancer & - & Overall survival & N.S. & 792 & TCGA & RNA Seq & \\
\hline$L E P R$ & Liver hepatocellular carcinoma & - & Overall survival & N.S. & 361 & TCGA & RNA Seq & \\
\hline$L E P R$ & Lung adenocarcinoma & - & Overall survival & N.S. & 475 & TCGA & RNA Seq & \\
\hline$L E P R$ & Ovarian serous cystadenocarcinoma & - & Overall survival & N.S. & 578 & TCGA & RNA Seq & \\
\hline$L E P R$ & Pancreatic adenocarcinoma & - & Overall survival & N.S. & 176 & TCGA & RNA Seq & \\
\hline$L E P R$ & Prostate adenocarcinoma & - & Overall survival & N.S. & 497 & TCGA & RNA Seq & \\
\hline$L E P R$ & Skin cutaneous melanoma & - & Overall survival & N.S. & 336 & TCGA & RNA Seq & \\
\hline$L E P R$ & Stomach adenocarcinoma & - & Overall survival & N.S. & 352 & TCGA & RNA Seq & \\
\hline$L E P R$ & Testicular germ cell tumors & - & Overall survival & N.S. & 133 & TCGA & RNA Seq & \\
\hline$L E P R$ & Thymoma & - & Overall survival & N.S. & 118 & TCGA & RNA Seq & \\
\hline$L E P R$ & Thyroid carcinoma & Poor & Overall survival & 0.0295 & 489 & TCGA & RNA Seq & \\
\hline$L E P R$ & $\begin{array}{l}\text { Uterine corpus endometrioid } \\
\text { carcinoma }\end{array}$ & - & Overall survival & N.S. & 332 & TCGA & RNA Seq & \\
\hline \multirow[t]{5}{*}{$L E P R$} & \multirow[t]{5}{*}{ Breast cancer } & Good & Overall survival & 0.051 & \multirow[t]{5}{*}{1402} & \multirow{5}{*}{$\begin{array}{c}\text { E-MTAB-365, E-TABM-43, GSE: } 11121, \\
\text { 12093, 12276, 1456, 16391, 16446, 16716, } \\
17705,17907,18728,19615,20194,20271, \\
2034,20685,20711,21653,2603,26971, \\
2990,31448,31519,32646,3494,37946, \\
41998,42568,45255,4611,5327,6532, \\
7390,9195\end{array}$} & \multirow[t]{5}{*}{ Array } & 207255_at \\
\hline & & Good & Overall survival & 0.0061 & & & & 209894_at \\
\hline & & Good & Overall survival & 0.053 & & & & 211354_s_at \\
\hline & & Good & Overall survival & 0.0057 & & & & 211355_x_at \\
\hline & & - & Overall survival & N.S. & & & & 211356_x_at \\
\hline$L E P R$ & Ovarian cancer & Poor & Overall survival & $8 \mathrm{E}-05$ & 1656 & $\begin{array}{c}\text { GSE: } 14764,15622,18520,19829,23554 \\
\text { 26193, } 26712,27651,30161,3149,51373 \\
63885,65986,9891, \text { TCGA }(\mathrm{N}=565)\end{array}$ & $\begin{array}{c}\text { Array } \\
\text { RNA Seq }\end{array}$ & 209894_at \\
\hline \multirow[t]{2}{*}{$L E P R$} & Lung cancer & Poor & Overall survival & 0.056 & 1926 & $\begin{array}{l}\text { CAARRAY, GSE: } 14814,19188,29013 \\
30219,31210,3141,31908,37745,43580\end{array}$ & Array & 207255_at \\
\hline & & Good & & $3 \mathrm{E}-11$ & & $4573,50081,8894$, TCGA $(\mathrm{N}=133)$ & RNA Seq & 209894_at \\
\hline \multirow[t]{5}{*}{$L E P R$} & Gastric cancer & Poor & Overall survival & $1 \mathrm{E}-06$ & 876 & $\begin{array}{c}\text { GSE: } 14210,15459,22377,29272,51105 \text {, } \\
62254\end{array}$ & Array & 207255_at \\
\hline & & Poor & & 0.0024 & & & & 209894_at \\
\hline & & Poor & & 0.0004 & & & & 211354_s_at \\
\hline & & Poor & & $8 \mathrm{E}-08$ & & & & $211355 \_x \_$at \\
\hline & & Poor & & $1 \mathrm{E}-06$ & & & & 211356_x_at \\
\hline$L E P R$ & Colorectal cancer & Poor & Disease free survival & 0.0006 & 55 & GSE17537 & Array & 209894_at \\
\hline$L E P R$ & Acute myeloid leukemia & Poor & Overall survival & 0.0029 & 58 & GSE5122 & Array & 207255_at \\
\hline$L E P R$ & Uveal melanoma & Good & Distant metastasis free survival & 0.0099 & 63 & GSE22138 & Array & 211356_x_at \\
\hline \multirow[t]{2}{*}{$L E P R$} & Colorectal cancer & Poor & Disease free survival & 0.0129 & 226 & GSE14333 & Array & 209894_at \\
\hline & & Poor & & 0.0391 & & & & 211355_x_at \\
\hline$L E P R$ & Colorectal cancer & Poor & Overall survival & 0.0139 & 62 & GSE12945 & Array & 211354_s_at \\
\hline$L E P R$ & Acute myeloid leukemia & Poor & Overall survival & 0.0168 & 79 & GSE12417-GPL570 & Array & 207255_at \\
\hline \multirow[t]{2}{*}{$L E P R$} & Soft tissue cancer & Good & Distant Recurrence Free Survival & 0.0194 & 140 & GSE30929 & Array & 209894_at \\
\hline & & Good & & 0.0347 & & & & 211356_x_at \\
\hline \multirow[t]{2}{*}{$L E P R$} & Colorectal cancer & Poor & Disease free survival & 0.0337 & 145 & GSE17536 & Array & 209894_at \\
\hline & & Poor & & 0.0387 & & & & 211354_s_at \\
\hline
\end{tabular}

Survival data was collected from database SurvExpress, TCGA and Kaplan Meier-plotter.

$L E P R$ : leptin receptor. N.S.: no significance. 


\section{Leptin and cancer metastasis}

In clinical data, the association of leptin and its receptor expression with bone metastasis was observed in patients of pulmonary adenocarcinoma [30]. In addition, cutaneous melanoma patients with relatively increasing leptin levels in serum samples revealed high risk of sentinel lymph node metastasis [31]. Another correlation analysis also showed the positive association of leptin and leptin receptor with lymph node metastasis in endometrial cancer [10]. In pancreatic cancer, hypoxia inducible factor (HIF)-1 $\alpha$, which associated with patient's metastasis stage and lymph node metastasis, could directly bind to hypoxiaresponsive element (HRE) located in $\mathrm{Ob}-\mathrm{R}$ gene promoter $(-828 /-832)$ and activated the downstream transcriptional activation, suggesting the potential clinical significance of leptin receptor mediated axis [32]. Actually, recombinant leptin was reported to notably promote ovarian cancer migration, invasion, peritoneal metastasis and epithelialmesenchymal transition (EMT) via signaling pathway PI3K/Akt/mTOR [13]. Furthermore, TGF $\beta 1$ was required for leptin-mediated EMT and metastatic ability in normal epithelial and cancer cell lines of breast (MCF7, MCF10A, MDA-MB-231 and MCF10AT1) [33]. In pancreatic cancer, leptin induced cancer cell migration/ invasion and metastasis in orthotopic model, and the simultaneously increased leptin receptor and MMP13 production displayed the positive correlation with patient's TNM stages [34]. Moreover, the studies with regard to anti-leptin-dependent cancer metastasis was explored. Adiponectin, also known as Acrp30, inhibited the leptinpromoted SPEC-2 endometrial cancer metastasis by inactivating JAK/STAT3 pathway via AMPK activation [35]. cAMP elevation also displayed the inhibitory effect to leptin-induced breast cancer MDA-MB-231 migration which was accompanied by a strong decrease of $\beta 3$ integrin subunit and focal adhesion kinase (FAK) protein levels [36]. The leptin-mediated OVCAR-3 ovarian cancer migration and MMP9 expression could be blocked by $17 \beta$-estradiol treatment [37]. Notably, a recent study in colon cancer pointed out that leptin upregulated miR-4443 to repress TRAF4 and NCOA1 expression leading to the decrease cancer invasion [38].

\section{Leptin and angiogenesis}

Leptin receptor appears to be expressed in various types of cancer, suggesting the leptin axis function other than appetite regulation. In human hepatocellular carcinoma, leptin/leptin receptor expressions were detected in both tumor and endothelial cells in parallel with the degree of angiogenesis [39]. In $92 \%$ of the colorectal carcinoma cases with pronounced leptin receptor expression, high rate of angiogenesis case was observed alone with the correlation of low grade neoangiogenesis and leptin receptor absence (88.2\% of the cases) [8]. In addition, the correlation of leptin receptor with vasculogenic mimicry (VM) formation had been reported in glioblastoma [15]. Moreover, HIF-1 $\alpha$ RNA and protein expression of leptin and leptin receptor were high in tissue samples of oral squamous cell carcinoma which indicated the potential crosslink in regulating angiogenesis [40]. Direct evidence had been revealed in the study of human chondrosarcoma cells. Leptin could induce VEGF-C expression and secretion leading to the lymphangiogenesis of human lymphatic endothelial cells via repressing miR-27b [41]. Induction of VEGF-A expression by leptin were found in melanoma tumor [42]. The leptinmediated regulation toward tube formation of endothelial progenitor cells was also shown in chondrosarcoma cell study. MAPK signaling was activated to enhance AP-1 binding to VEGF-A promoter for transactivation by leptinleptin receptor axis in cancer cells [43]. Furthermore, HIF- $1 \alpha$ and NFKB were proposed as the major route in leptin-dependent VEGF-A induction in breast cancer [44]. The biological significance of leptin-leptin receptor axis in promoting angiogenesis was further shown by the inhibitory effect of Aca 1 treatment, a peptide leptin receptor antagonist, on endothelial cell tube formation [45], as well as by the Allo-aca (leptin receptor antagonist)mediated reduction of pathological vascularization in rat ophthalmic neoangiogenesis model [46].

\section{Leptin and drug resistance}

Emerging studies referred to the involvement of leptin axis in drug resistance. Leptin levels in serum were higher in patients of pancreatic adenocarcinoma, and associated with gemcitabine chemotherapy [47]. In gastrooesophageal adenocarcinomas, high leptin expression displayed the resistance to cisplatin, though the effect was not significant to oxaliplatin or 5-fluorouracil [48]. In experimental model of AGS Cis5 and OE33 cell lines, SHLA (leptin receptor antagonist) treatment increased cisplatin sensitivity [48]. The result from another group further pointed out leptin could induce cancer progression and relative molecule expression including $\mathrm{ABCB} 1$ protein in pancreatic cancer [49]. Bortezomib-induced toxicity was attenuated accompanying the expression of cyclinD1, Bcl-2 and decreased caspase 3 by leptin addition [14]. Leptin might further regulate stress response and metabolism that cisplatin-induced cytotoxicity in breast tumor cell MCF-7 decreased by leptin alone with SIRT1 upregulation [50]. Similar observation was found that leptin overexpression decreased cisplatin-dependent ER stress unfolded protein response pathways, PERK and ATF6, to induce lung adenocarcinoma A549 cell proliferation [51]. Furthermore, overexpression of leptin receptor led to temozolomide (TMZ) resistance due to the stem/progenitor cell properties, and STAT3 signaling in glioblastoma [52]. Leptin addition attended to block ICI 182,780-mediated therapeutic effects on breast cancer MCF-7 cell proliferation, suggesting the involvement of estrogen signaling axis in drug resistance [53]. However, a 
survival analysis study indicated the disease-free survival of the tamoxifen-treated postmenopausal obese patients was better in leptin-positive group [54].

\section{Summary and perspectives}

According to the previous findings in publications and in silico analysis from the clinical cancer databases, the expressions of leptin and leptin receptor are found in many types of cancer. The signaling axis also plays critical role in regulating several key processes of cancer progression, including cell proliferation, metastasis, angiogenesis and drug resistance. We demonstrated the relative expression level of leptin and leptin receptor in a pan-cancer panel, and revealed the dramatic upregulation of the leptin-leptin receptor axis in breast cancer, head and neck cancer, lung cancer, ovarian cancer and pancreatic cancer, suggesting the potential critical role of this signaling node in tumor progression. The differential RNA expression in specific cancer types suggest the potential alternation in upstream transcriptional activity and RNA stability that might be of value for further investigations in tumorigenesis and cancer progression. In clinical, leptin and leptin receptor serves as poor prognostic markers in variant types of cancer including ovarian cancer, colon cancer, AML, gastric cancer, while the prediction of good outcome by the same axis has also been observed in soft tissue cancer. This might result from potential involvement of other signaling in complicated interaction network contributing to the different outcomes in specific caner type. Obviously, the prognostic function of the axis in breast cancer is currently under debate which might be due to the variances in analytic platform and endpoint that remains to be explored. It is noted the difference in amount of cases enrolled in cohorts also limit the prognostic power, and sufficient patient number for predicting the outcome and reflecting the reality is hard to be determined. Because there have been a few of reports showing discrepancies regarding leptin-leptin receptor axis's function in cancer progression, expression level and clinical outcome, the role of leptin-mediated signaling in promoting or inhibiting cancer progression is still unclear in cancer of specific type. In addition to the variation in the experimental procedures, another possibility is that the leptin-mediated stimulatory or inhibitory effects are partly altered by other receptors in various types of cancer. It is noted that the relative expression levels of leptin and leptin receptor were not uniformly distributed in the pancancer cohort, which provides a basis for the pathological involvement of other leptin receptors in tumors, which requires further exploration.

\section{ACKNOWLEDGMENTS}

We thank for the help from Genomic Medicine Core Laboratory, Chang Gung Memorial Hospital, Linkou, Taiwan.

\section{CONFLICTS OF INTEREST}

The authors declare that there are no conflicts of interest.

\section{FUNDING}

This study was funded by Academia Sinica and Ministry of Science and Technology (MOST 104-021001-09-02, MOST 105-0210-01-13-01, MOST 106-021001-15-02), Taiwan to Dr. Michael Hsiao, and by Chang Gung Memorial Hospital, Linkou (CMRPG3G0611) and Ministry of Science and Technology (MOST 106-2314-B-182A-004-MY2), Taiwan to Dr. TsungChieh Lin.

\section{REFERENCES}

1. Zhang Y, Proenca R, Maffei M, Barone M, Leopold L, Friedman JM. Positional cloning of the mouse obese gene and its human homologue. Nature. 1994; 372:425-32. https://doi.org/10.1038/372425a0.

2. Tartaglia LA, Dembski M, Weng X, Deng N, Culpepper J, Devos R, Richards GJ, Campfield LA, Clark FT, Deeds J, Muir C, Sanker S, Moriarty A, et al. Identification and expression cloning of a leptin receptor, OB-R. Cell. 1995; 83:1263-71.

3. Halaas JL, Gajiwala KS, Maffei M, Cohen SL, Chait BT, Rabinowitz D, Lallone RL, Burley SK, Friedman JM. Weight-reducing effects of the plasma protein encoded by the obese gene. Science. 1995; 269:543-6.

4. Senaris R, Garcia-Caballero T, Casabiell X, Gallego R, Castro R, Considine RV, Dieguez C, Casanueva FF. Synthesis of leptin in human placenta. Endocrinology. 1997; 138:4501-4. https://doi.org/10.1210/endo.138.10.5573.

5. Bado A, Levasseur S, Attoub S, Kermorgant S, Laigneau JP, Bortoluzzi MN, Moizo L, Lehy T, Guerre-Millo M, Le Marchand-Brustel Y, Lewin MJ. The stomach is a source of leptin. Nature. 1998; 394:790-3. https://doi. org/10.1038/29547.

6. Lin TC, Lee TC, Hsu SL, Yang CS. The molecular mechanism of leptin secretion and expression induced by aristolochic acid in kidney fibroblast. PLoS One. 2011; 6:e16654. https://doi.org/10.1371/journal.pone.0016654.

7. Wang J, Liu R, Hawkins M, Barzilai N, Rossetti L. A nutrient-sensing pathway regulates leptin gene expression in muscle and fat. Nature. 1998; 393:684-8. https://doi. org $/ 10.1038 / 31474$.

8. Milosevic VS, Vukmirovic FC, Krstic MS, Zindovic MM, Lj Stojanovic D, Jancic SA. Involvement of leptin receptors expression in proliferation and neoangiogenesis in colorectal carcinoma. J BUON. 2015; 20:100-8.

9. Zhu J, Sanborn JZ, Benz S, Szeto C, Hsu F, Kuhn RM, Karolchik D, Archie J, Lenburg ME, Esserman LJ, Kent WJ, Haussler D, Wang T. The UCSC cancer genomics 
browser. Nat Methods. 2009; 6:239-40. https://doi. org/10.1038/nmeth0409-239.

10. Zhang Y, Liu L, Li C, Ai H. Correlation analysis between the expressions of leptin and its receptor (ObR) and clinicopathology in endometrial cancer. Cancer Biomark. 2014; 14:353-9. https://doi.org/10.3233/CBM-140415.

11. Kumar J, Fang H, McCulloch DR, Crowley T, Ward AC. Leptin receptor signaling via Janus kinase 2/Signal transducer and activator of transcription 3 impacts on ovarian cancer cell phenotypes. Oncotarget. 2017; 8:9353040. https://doi.org/10.18632/oncotarget.19873.

12. Sultana R, Kataki AC, Borthakur BB, Basumatary TK, Bose $\mathrm{S}$. Imbalance in leptin-adiponectin levels and leptin receptor expression as chief contributors to triple negative breast cancer progression in Northeast India. Gene. 2017; 621:518. https://doi.org/10.1016/j.gene.2017.04.021.

13. Wei X, Liu Y, Gong C, Ji T, Zhou X, Zhang T, Wan D, Xu S, Jin P, Yang X, Li X, Ma D, Yang Z, et al. Targeting leptin as a therapeutic strategy against ovarian cancer peritoneal metastasis. Anticancer Agents Med Chem. 2017; 17:1093101. https://doi.org/10.2174/1871520616666161221114454.

14. Yu W, Cao DD, Li QB, Mei HL, Hu Y, Guo T. Adipocytes secreted leptin is a pro-tumor factor for survival of multiple myeloma under chemotherapy. Oncotarget. 2016; 7:8607586. https://doi.org/10.18632/oncotarget.13342.

15. Han G, Li Y, Cao Y, Yue Z, Zhang Y, Wang L, Liu J. Overexpression of leptin receptor in human glioblastoma: correlation with vasculogenic mimicry and poor prognosis. Oncotarget. 2017; 8:58163-71. https://doi.org/10.18632/ oncotarget. 17344.

16. Lee YC, Wu WJ, Lin HH, Li WM, Huang CN, Hsu WC, Chang LL, Li CC, Yeh HC, Li CF, Ke HL. Prognostic value of leptin receptor overexpression in upper tract urothelial carcinomas in Taiwan. Clin Genitourin Cancer. 2017; 15:e653-e9. https://doi.org/10.1016/j.clgc.2017.01.002.

17. Khabaz MN, Abdelrahman A, Butt N, Damnhory L, Elshal M, Aldahlawi AM, Ashoor S, Al-Maghrabi B, Dobson P, Brown B, Al-Sakkaf K, Al-Qahtani M, Al-Maghrabi J. Immunohistochemical staining of leptin is associated with grade, stage, lymph node involvement, recurrence, and hormone receptor phenotypes in breast cancer. BMC Womens Health. 2017; 17:105. https://doi.org/10.1186/ s12905-017-0459-y.

18. Mendoza-Perez J, Gu J, Herrera LA, Tannir NM, Zhang S, Matin S, Karam JA, Wood CG, Wu X. Prognostic significance of promoter $\mathrm{CpG}$ island methylation of obesity-related genes in patients with nonmetastatic renal cell carcinoma. Cancer. 2017; 123:3617-27. https://doi. org/10.1002/cncr.30707.

19. Aguirre-Gamboa R, Gomez-Rueda H, Martinez-Ledesma E, Martinez-Torteya A, Chacolla-Huaringa R, RodriguezBarrientos A, Tamez-Pena JG, Trevino V. SurvExpress: an online biomarker validation tool and database for cancer gene expression data using survival analysis. PLoS
One. 2013; 8:e74250. https://doi.org/10.1371/journal. pone. 0074250 .

20. Gyorffy B, Schafer R. Meta-analysis of gene expression profiles related to relapse-free survival in 1,079 breast cancer patients. Breast Cancer Res Treat. 2009; 118:43341. https://doi.org/10.1007/s10549-008-0242-8.

21. Chen C, Chang YC, Lan MS, Breslin M. Leptin stimulates ovarian cancer cell growth and inhibits apoptosis by increasing cyclin D1 and Mcl-1 expression via the activation of the MEK/ERK1/2 and PI3K/Akt signaling pathways. Int J Oncol. 2013; 42:1113-9. https://doi. org/10.3892/ijo.2013.1789.

22. Wang J, Cheng Y, Yin X, Wu J, Luo Y, Di J, Liu D, Huang Y, Zhang R, Zhang J. Globular adiponectin inhibits leptinstimulated esophageal adenocarcinoma cell proliferation via adiponectin receptor 2-mediated suppression of UHRF1. Mol Cell Biochem. 2017; 431:103-12. https://doi. org/10.1007/s11010-017-2980-6.

23. Martin R, Cordova C, Gutierrez B, Hernandez M, Nieto ML. A dangerous liaison: leptin and sPLA2-IIA join forces to induce proliferation and migration of astrocytoma cells. PLoS One. 2017; 12:e0170675. https://doi.org/10.1371/ journal.pone. 0170675 .

24. Feng X, Han H, Zou D, Zhou J, Zhou W. Suberoylanilide hydroxamic acid-induced specific epigenetic regulation controls Leptin-induced proliferation of breast cancer cell lines. Oncotarget. 2017; 8:3364-79. https://doi. org/10.18632/oncotarget.13764.

25. Hosney M, Sabet S, El-Shinawi M, Gaafar KM, Mohamed MM. Leptin is overexpressed in the tumor microenvironment of obese patients with estrogen receptor positive breast cancer. Exp Ther Med. 2017; 13:2235-46. https://doi.org/10.3892/etm.2017.4291.

26. Strong AL, Ohlstein JF, Biagas BA, Rhodes LV, Pei DT, Tucker HA, Llamas C, Bowles AC, Dutreil MF, Zhang S, Gimble JM, Burow ME, Bunnell BA. Leptin produced by obese adipose stromal/stem cells enhances proliferation and metastasis of estrogen receptor positive breast cancers. Breast Cancer Res. 2015; 17:112. https://doi.org/10.1186/ s13058-015-0622-z.

27. Ding Y, Cao Y, Wang B, Wang L, Zhang Y, Zhang D, Chen X, Li M, Wang C. APPL1-mediating leptin signaling contributes to proliferation and migration of cancer cells. PLoS One. 2016; 11:e0166172. https://doi.org/10.1371/ journal.pone.0166172.

28. Thompson KJ, Lau KN, Johnson S, Martinie JB, Iannitti DA, McKillop IH, Sindram D. Leptin inhibits hepatocellular carcinoma proliferation via p38-MAPKdependent signalling. HPB (Oxford). 2011; 13:225-33. https://doi.org/10.1111/j.1477-2574.2010.00259.x.

29. Zou H, Liu Y, Wei D, Wang T, Wang K, Huang S, Liu L, Li Y, Ge J, Li X, Zhu H, Wang L, Zhao S, et al. Leptin promotes proliferation and metastasis of human gallbladder cancer through OB-Rb leptin receptor. Int J Oncol. 2016; 49:197-206. https://doi.org/10.3892/ijo.2016.3530. 
30. Feng HL, Guo P, Wang J, Liu QY, Xu JF, Yang HC, Zhang JM. [Association of the expression of leptin and leptin receptor with bone metastasis in pulmonary adenocarcinoma]. [Article in Chinese]. Zhonghua Zhong Liu Za Zhi. 2016; 38:840-4. https://doi.org/10.3760/cma.j .issn.0253-3766.2016.11.008.

31. Oba J, Wei W, Gershenwald JE, Johnson MM, Wyatt CM, Ellerhorst JA, Grimm EA. Elevated serum leptin levels are associated with an increased risk of sentinel lymph node metastasis in cutaneous melanoma. Medicine (Baltimore). 2016; 95:e3073. https://doi.org/10.1097/ MD.0000000000003073.

32. Ren H, Jia L, Zhao T, Zhang H, Chen J, Yang S, Liu J, Yu M, Hao J. Hypoxia inducible factor (HIF)-1alpha directly activates leptin receptor (Ob-R) in pancreatic cancer cells. Cancer Lett. 2014; 354:172-80. https://doi.org/10.1016/j. canlet.2014.08.001.

33. Mishra AK, Parish CR, Wong ML, Licinio J, Blackburn AC. Leptin signals via TGFB1 to promote metastatic potential and stemness in breast cancer. PLoS One. 2017; 12:e0178454. https://doi.org/10.1371/journal. pone. 0178454 .

34. Fan Y, Gan Y, Shen Y, Cai X, Song Y, Zhao F, Yao M, Gu J, $\mathrm{Tu}$ H. Leptin signaling enhances cell invasion and promotes the metastasis of human pancreatic cancer via increasing MMP-13 production. Oncotarget. 2015; 6:16120-34. https:// doi.org/10.18632/oncotarget.3878.

35. Wu X, Yan Q, Zhang Z, Du G, Wan X. Acrp30 inhibits leptin-induced metastasis by downregulating the JAK/ STAT3 pathway via AMPK activation in aggressive SPEC-2 endometrial cancer cells. Oncol Rep. 2012; 27:1488-96. https://doi.org/10.3892/or.2012.1670.

36. Spina A, Di Maiolo F, Esposito A, Sapio L, Chiosi E, Sorvillo L, Naviglio S. cAMP elevation down-regulates beta3 integrin and focal adhesion kinase and inhibits leptin-induced migration of MDA-MB-231 breast cancer cells. Biores Open Access. 2012; 1:324-32. https://doi. org/10.1089/biores.2012.0270.

37. Hoffmann M, Fiedor E, Ptak A. 17 $\beta$-estradiol reverses leptin-inducing ovarian cancer cell migration by the PI3K/ Akt signaling pathway. Reprod Sci. 2016; 23:1600-8. https://doi.org/10.1177/1933719116648214.

38. Meerson A, Yehuda H. Leptin and insulin up-regulate miR4443 to suppress NCOA1 and TRAF4, and decrease the invasiveness of human colon cancer cells. BMC Cancer. 2016; 16:882. https://doi.org/10.1186/s12885-016-2938-1.

39. Ribatti D, Belloni AS, Nico B, Di Comite M, Crivellato E, Vacca A. Leptin-leptin receptor are involved in angiogenesis in human hepatocellular carcinoma. Peptides. 2008; 29:1596-602. https://doi.org/10.1016/j. peptides.2008.05.011.

40. Sobrinho Santos EM, Guimaraes TA, Santos HO, Cangussu LM, de Jesus SF, Fraga CA, Cardoso CM, Santos SH, de Paula AM, Gomez RS, Guimaraes AL, Farias LC. Leptin acts on neoplastic behavior and expression levels of genes related to hypoxia, angiogenesis, and invasiveness in oral squamous cell carcinoma. Tumour Biol. 2017; 39:1010428317699130. https://doi. org/10.1177/1010428317699130.

41. Yang WH, Chang AC, Wang SW, Wang SJ, Chang YS, Chang TM, Hsu SK, Fong YC, Tang CH. Leptin promotes VEGF-C production and induces lymphangiogenesis by suppressing miR-27b in human chondrosarcoma cells. Sci Rep. 2016; 6:28647. https://doi.org/10.1038/srep28647.

42. Amjadi F, Mehdipoor R, Zarkesh-Esfahani H, Javanmard $\mathrm{SH}$. Leptin serves as angiogenic/mitogenic factor in melanoma tumor growth. Adv Biomed Res. 2016; 5:127. https://doi.org/10.4103/2277-9175.187005.

43. Yang WH, Chen JC, Hsu KH, Lin CY, Wang SW, Wang SJ, Chang YS, Tang CH. Leptin increases VEGF expression and enhances angiogenesis in human chondrosarcoma cells. Biochim Biophys Acta. 2014; 1840:3483-93. https://doi. org/10.1016/j.bbagen.2014.09.012.

44. Gonzalez-Perez RR, Xu Y, Guo S, Watters A, Zhou W, Leibovich SJ. Leptin upregulates VEGF in breast cancer via canonic and non-canonical signalling pathways and NFkappaB/HIF-1alpha activation. Cell Signal. 2010; 22:1350-62. https://doi.org/10.1016/j.cellsig.2010.05.003.

45. Ferla R, Bonomi M, Otvos L Jr, Surmacz E. Glioblastoma-derived leptin induces tube formation and growth of endothelial cells: comparison with VEGF effects. BMC Cancer. 2011; 11:303. https://doi. org/10.1186/1471-2407-11-303.

46. Coroniti R, Fario R, Nuno DJ, Otvos L, Scolaro L, Surmacz E. Designer leptin receptor antagonist allo-aca inhibits VEGF effects in ophthalmic neoangiogenesis models. Front Mol Biosci. 2016; 3:67. https://doi.org/10.3389/ fmolb.2016.00067.

47. Karabulut S, Usul Afsar C, Karabulut M, Alis H, Erturk K, Karaman S, Kones O, Bilgin E, Tas F. Serum leptin levels may have diagnostic and predictive roles in patients with pancreatic adenocarcinoma treated with gemcitabine-based chemotherapy. J BUON. 2016; 21:895-902.

48. Bain GH, Collie-Duguid E, Murray GI, Gilbert FJ, Denison A, McKiddie F, Ahearn T, Fleming I, Leeds J, Phull P, Park K, Nanthakumaran S, Grabsch HI, et al. Tumour expression of leptin is associated with chemotherapy resistance and therapy-independent prognosis in gastro-oesophageal adenocarcinomas. Br J Cancer. 2014; 110:1525-34. https:// doi.org/10.1038/bjc.2014.45.

49. Harbuzariu A, Rampoldi A, Daley-Brown DS, Candelaria P, Harmon TL, Lipsey CC, Beech DJ, Quarshie A, Ilies GO, Gonzalez-Perez RR. Leptin-Notch signaling axis is involved in pancreatic cancer progression. Oncotarget. 2017; 8:774052. https://doi.org/10.18632/oncotarget.13946.

50. Nadal-Serrano M, Sastre-Serra J, Valle A, Roca P, Oliver J. Chronic-leptin attenuates Cisplatin cytotoxicity in MCF-7 breast cancer cell line. Cell Physiol Biochem. 2015; 36:22132. https://doi.org/10.1159/000374066. 
51. Lai Q, Sun Y. Human leptin protein induces proliferation of A549 cells via inhibition of PKR-like ER kinase and activating transcription factor-6 mediated apoptosis. Yonsei Med J. 2013; 54:1407-15. https://doi.org/10.3349/ ymj.2013.54.6.1407.

52. Han G, Wang L, Zhao W, Yue Z, Zhao R, Li Y, Zhou X, $\mathrm{Hu} \mathrm{X}$, Liu J. High expression of leptin receptor leads to temozolomide resistance with exhibiting stem/progenitor cell features in gliobalastoma. Cell Cycle. 2013; 12:383340. https://doi.org/10.4161/cc.26809.
53. Garofalo C, Sisci D, Surmacz E. Leptin interferes with the effects of the antiestrogen ICI 182,780 in MCF-7 breast cancer cells. Clin Cancer Res. 2004; 10:6466-75. https:// doi.org/10.1158/1078-0432.CCR-04-0203.

54. Kim Y, Kim SY, Lee JJ, Seo J, Kim YW, Koh SH, Yoon HJ, Cho KS. Effects of the expression of leptin and leptin receptor (OBR) on the prognosis of early-stage breast cancers. Cancer Res Treat. 2006; 38:126-32. https://doi. org/10.4143/crt.2006.38.3.126. 